\title{
外傷性脳損傷発生における力学的評価ならびに 脳損傷の定量的評価に関する研究
}

\section{第 2 篇 脳損傷の定量的評価に関する臨床的研究 \\ 一ととに急性硬膜下血腫における脳損傷の \\ 評価と FDP 測定の意義一}

関西医科大学脸神経外科（指導主任：松村 浩教授)

大学院生 水 野誠

（昭和63年 2 月 19 日受付）

索引用眖 : 急性硬膜下血腫, 脳損傷, 脳嗹脹, FDP, 予後

I. 緒言
II. 対象および方法
III. 結果

1）治療および予後

目次

\section{2 ）予後関連因子}

IV. 考案

V. まとめ

\section{I. 腥 曹}

第 1 篇において重症頭部外傷の予後は外傷によって発 生する脳損傷の種類と程度, さらに加わった外力の大き さが密接に関与することを示し, 間接的ではあっても外 力の評価が重要な意味を持つことを明らかにし，脳損傷 発生機序について考察した。しかしながら，より正確な 診断予後予測を考える上で初回 CTによる脳病変の形態 的評価のみでは十分でないこと，さらに外力の評価は臨 床的に注残念ながら間接的にとどまらざるを得ないこと も明らかとなった。

そこで, 第 2 篇において頭部外傷の予後と密接な相関 が考えられる脳損傷の定性定量的評価について研究を行 った.

線溶凝固系の血清学的検査はしばしば日常臨床におい て用いられているが，これらの内 fibrin \& fibrinogen degradation products (FDP) については脳組織が大量 の組織トロンボプラスチンを含むことより脳組織損傷の 程度をある程度反映することが諸家により指摘されてい る12) 19) 24) 25). 一方, 急性硬膜下血腫は頭部外傷中最 も予後不良な病態として知られ，その原因として脳挫
傷, 浮腫の存在が指摘されている91 15) 22) 27) 28). (か しながら, 初回の CT より脸損傷の有無や程度を完全 にとらえることは CT の空間分解能や partial volume effect のため常に可能ではない21) 27)。 またその病態生 理についても不明の点が多い。

そこで著者は急性硬膜下血腫例を対象としてその予後 を分界する臨床的因子， CT より把握し得る脳病变につ いて分析検討を行うと共に受傷早期に FDP 測定を行い, CT から得られる種々の病態や予後と対比検討を行っ た. そして FDP 測定の意義, すなわち脳損傷の定量的 評価が可能かどうか, さらに急性硬膜下血腫における脳 損傷の定量的評価の意義について知見を得たので報告す る. またこれらの結果を踏まえ, 急性硬膜下血腫に抢け る病態生理について考察する.

\section{II. 対象および方法}

対象は，1982年 1 月から1984年 4 月までに，当大学お よび関連施設において経験した成人急性硬膜下血腫62例 （男性 50例, 女性 12例) で, 全例受傷後 24 時間以内に搬 送され初回 CT scan を施行し, 上記と診断した症例で ある. 入院時の神経学的重症度は, Glasgow Coma Scale 
(GCS) 20) にて評価し，さらに瞳孔反応，除脳硬直等の 脳幹徴候も含めて 検討した. また, 初回 CT 所見から は，硬膜下血腯の最大巾 thickness $(\mathrm{T})$ および正中構造 の偏位巾 midline shift (M) を計測し, さらに脳実質損 傷の程度を評価した.なお，Mは正中線と透明中隔部と の距離で表わし，脳実質所見は山浦らの報告27) 亿従い， isodensity without mass effect- $I(-)$, isodensity with mass effect- $I(+)$, high density- $(H)$, high and low density complex-(H-L), low density-(L) 飞分類し検 討した。 また，19例において患者搬送直後に末梢血を採 取し，Latex 凝集反応による帝国臓器社製 FDP-L test kit を使用し，血中濃度 FDP level を測定した．予後は 受傷後 6 力月の時点で, Glasgow Outcome Scale $(\mathrm{GOS})^{5}$ すなわち good recovery (GR), moderate disability (MD), severe disability (SD), vegetative state (VS), death (D) の 5 段階を用いて評価した。 そして GR およ び MDを予後良好群 (G群), SD，VS およびDを予後 不良群 (P群) とし, 各群と上記の予後判定因子との相 関性を分析した。

\section{III. 結 果}

\section{1) 治寮および予後 (Table 1)}

手術は46例 $(74.2 \%)$ 亿施行し, 残りの16例は神経学 的に良好であるかあるい㥛めて重篤なために保存的治 療を行った例である. 著者は従来より, 急性硬膜下血腫 に対する治療法として血腫除去十広範囲減圧開頭術を行 うことを原則としており，今回の series でも30例にこ れを施行した．他は脳浮腫が軽度のため単純に血腫のみ 除去したものが12例，著しい脳腫脹のため内隇圧を追加
Table 1 Outcome of acute subdural hematoma in the present series. GOS stands for Glasgow Outcome Scale.

\begin{tabular}{lc}
\hline \multicolumn{1}{c}{ Outcome (GOS) } & Number \\
\hline Good & 18 cases \\
- good recovery & $14(22.6 \%)$ \\
- moderate disability & $4(6.5 \%)$ \\
\hline Poor & 44 cases \\
- severe disability & $10(16.1 \%)$ \\
- vegetative state & $2(3.2 \%)$ \\
- death & $32(51.6 \%)$ \\
\hline Total & 62 cases \\
\hline
\end{tabular}

したものが 4 例である.

予後汇関しては, GR 14例 (22.6\%), MD 4 例 (6.5 $\%)$, SD 10例 (16.1\%), VS 2例 (3.2\%), D 32例 (51.6\%) であり, 従ってG群は18例 (29.1\%), P群は 44例 (70.9\%) となり，今回の著者の series でも諸家 の報告と同様に重篤な結果であった 22) 27)。このように 予後を分界する要因を知る目的で下記の臨床的諸因子に ついて検討を行った.

\section{2) 予後関連因子}

\section{(1)年齢（Fig. 1)}

年齢は15〜83歳，平均 50.8 嵗であったが，G群では平 均45.5歳，P群では平均 53.0 歳で両群に有意な差はない ものの，年代別の検討では Fig. 1 のごとく65歳以上で P 群の占める割合が高い。

(2)入院時 GCS score (Fig. 2)

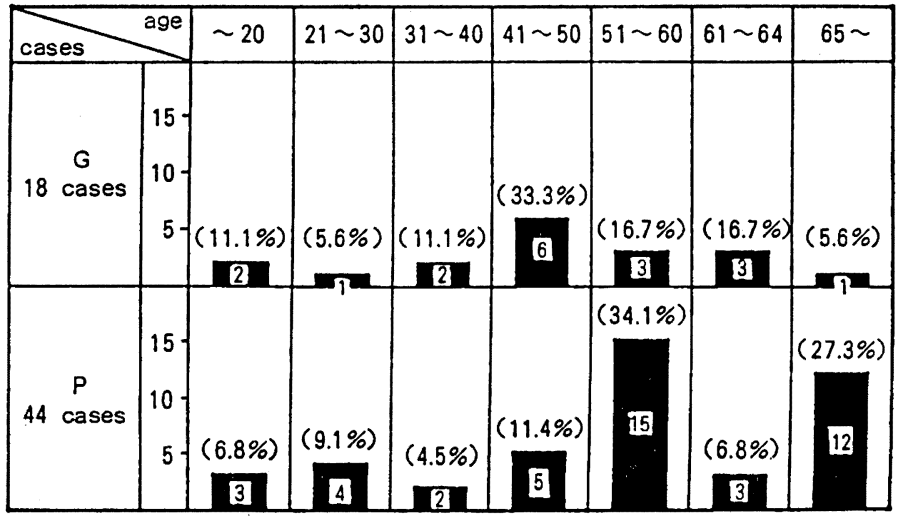

Fig. 1 The figure shows relationship of age and outcome.

G : good outcome group (good recovery, moderate disability)

P : poor outcome group (severe disability, vegetative state, death) 


\begin{tabular}{|c|c|c|c|c|c|}
\hline \multicolumn{6}{|c|}{ GCS score } \\
\hline 14 & 0000 & $\bullet$ & & & $\bullet$ \\
\hline 13 & $\bullet$ & & & & $\bullet$ \\
\hline 12 & $\bullet \bullet \bullet$ & & & $\bullet$ & $\bullet$ \\
\hline 11 & & & - & & \\
\hline 10 & $\bullet \bullet$ & - & - & & \\
\hline 9 & $\bullet$ & & - & & - \\
\hline 8 & & & & & - \\
\hline 7 & $\bullet \bullet \bullet$ & & & & $\bullet$ \\
\hline 6 & & & $\bullet$ & & $\bullet \bullet \bullet \bullet$ \\
\hline 5 & & & $\bullet \bullet \bullet \bullet$ & - & $\bullet \bullet \bullet \bullet \bullet \bullet \bullet$ \\
\hline 4 & & & $\bullet$ & & - \\
\hline 3 & & $\bullet$ & & & $888888^{\circ}$ \\
\hline & $\begin{array}{l}\text { good } \\
\text { recovery }\end{array}$ & $\begin{array}{l}\text { moderate } \\
\text { disability }\end{array}$ & $\begin{array}{l}\text { severe } \\
\text { disability }\end{array}$ & $\begin{array}{r}\text { vegetative } \\
\text { state }\end{array}$ & death \\
\hline
\end{tabular}

Fig. 2 The figure shows GCS scores on admission and their outcome. Mean GCS score in the good outcome group (good recovery, moderate disability) is 10.9 and that in the poor outcome group (severe disability, vegetative state, death) is 5.9 . GCS stands for Glasgow Coma Scale.

Table 2 Relationship of pupillary changes and decerebration on admission with their outcome.

Pupil

\begin{tabular}{cccccc}
$\begin{array}{c}\text { Pupil } \\
\text { Outcome }\end{array}$ & $\begin{array}{c}\text { Isocoria } \\
\text { LR prompt }\end{array}$ & $\begin{array}{c}\text { Anisocoria } \\
\text { LR sluggish }\end{array}$ & $\begin{array}{c}\text { Isocoria } \\
\text { LR none }\end{array}$ & $\begin{array}{c}\text { Anisocoria } \\
\text { LR none }\end{array}$ & $\begin{array}{c}\text { Dilated } \\
\text { pupil }\end{array}$ \\
\hline $\begin{array}{c}\text { G } \\
\text { cases })\end{array}$ & $\begin{array}{c}17 \\
(61.1 \%)\end{array}$ & $\begin{array}{c}5 \\
(27.8 \%)\end{array}$ & $\begin{array}{c}1 \\
(5.6 \%)\end{array}$ & $\begin{array}{c}7 \\
(5.6 \%)\end{array}$ & 0 \\
\hline $\begin{array}{l}\text { P } \\
\text { cases })\end{array}$ & $(18.2 \%)$ & $(18.2 \%)$ & $(16.0 \%)$ & $(22.7 \%)$ & $(25.0 \%)$ \\
\hline Mortality & $\left.(2)^{8} \%\right)$ & $(38.5 \%)$ & $(62.5 \%)$ & $(63.6 \%)$ & $(100 \%)$ \\
\hline
\end{tabular}

Decerebration

\begin{tabular}{|c|c|c|}
\hline Decerebraion & + & - \\
\hline G. & 0 & 18 \\
\hline$P$ & 8 & 36 \\
\hline Mortality & $\begin{array}{c}5 \\
(62.5 \%)\end{array}$ & $(50 \%)$ \\
\hline
\end{tabular}

入院時 GCS score は 3〜14で平均7.4であった. 予後 別にみると, GRを示した症例は平均11.1, MD注10.3， $\mathrm{SD}$ は6.6, VS は8.5, Dは5.5であり子後との相関性を 認める. 特に $\mathrm{G}$ 群（平均 10.9）と $\mathrm{P}$ 群（平均 5.9）との
G : good outcome group (good recovery, moderate disability)

P : poor outcome group (severe disability, vegetative state, death)

LR : light reaction

間には 統計学的に 有意な差を認め GCS score 6 以下で は34例中33例 (97\%) がP群にあり, さらに GCS score が 4 以下になると mortality は81\%となった.

(3)瞳孔反応および除脳硬直（Table 2) 
脳幹徴候である 瞳孔反応および 除脳硬直伔ついては Table 2 に示した. 予後良好群では isocoria with prompt light reaction (LR) sluggish LR が 5 例 $(27.8 \%)$ と少なくとも対光反射 がわずかでも保たれている例が大半を占めている（88.9 \%)。一方，予後不良群では対光反射が消失した症例が

Table 3 Thickness of subdural hematoma and midline shift on initial CT, compared with their outcome.

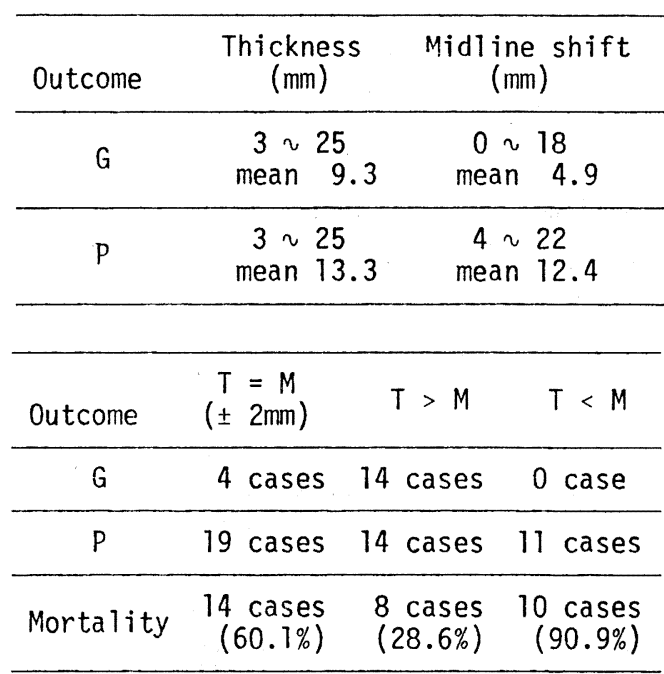

$\mathrm{T}:$ maximum thickness of subdural hematoma on initial CT (mm)

$M:$ midline shift $(\mathrm{mm})$

G : good outcome group (good recovery, moderate disability)

$\mathrm{P}$ : poor outcome group (severe disability, vegetative state, death)
63.7\%を占めており，その $76.7 \%$ 多亡した。 すなわ ち，対光反射の存在の有無が予後良好・不良を分界する critical sign であった。 また，除脳硬直が存在する例も 全例予後不良で，62.5\%の mortality を示した.

(4)CT 所見 (Table 3, 4)

G 群では Tは $3 \sim 25 \mathrm{~mm}$ 平均 $9.3, \mathrm{M}$ は $0 \sim 18 \mathrm{~mm}$ 平均 4.9亿対し，P群ではTは $3 \sim 25 \mathrm{~mm}$ 平均 $13.3, \mathrm{M}$ は 4 〜 $22 \mathrm{~mm}$ 平均 12.4 であった．すなわち血腫巾および正中偏位 ともにP群の方が程度が強い傾向にある.ささら， Tと Mの CT 測定值より Table 3 のごとく $\mathrm{T}=\mathrm{M}, \mathrm{T}>\mathrm{M}$, $\mathrm{T}<\mathrm{M}$ 亿分類したところ， G 群では血腫巾が正中偏位を 上回るもの $(\mathrm{T}>\mathrm{M})$ が多く, 一方 $\mathrm{P}$ 群では正中偏位が 血腫巾を上回るもの（ $\mathrm{T}<\mathrm{M} ）$ が多い，すなわち，血腫 量に比較し正中偏位が強いものの方が予後不良であり, mortality : $\mathrm{T}>\mathrm{M}$ で 30\%, $\mathrm{T}=\mathrm{M}$ で 60\%, $\mathrm{T}<\mathrm{M}$ で は90\%に達した（Table 3).

山浦ら ${ }^{27)}$ に従った CT 上の脳実質損傷の分類と予後 との相関性については Table 4 に示した。 G群では I (-) が 11例 (61.1\%)，I（+）と Hがそれぞれ 2 例 (11.1\%)，H-Lが 3 例 (16.7\%) で過半数が I (-) で 占められている. 一方 P 群では $\mathrm{G}$ 群と対照的に I (-) が 5 例 (11.4\%)，I (+) が19例 $(43.2 \%), \mathrm{H}$ が 6 例 (13.6\%)，H-Lが 13例 (30.2\%)，L が 1例 (2.3\%) であり I (+), H-L, Hの頻度が高い (Table 4). (5)血中 FDP

血中 FDP level は頭部のみを打撲したと考えられる 19例について 搬送直後に 末梢血より採血し測定した. FDP level と予後との相関（Fig. 3) では， G群平均 $12.9 \mu \mathrm{g} / \mathrm{m} \ell, \quad \mathrm{P}$ 群平均 $101.3 \mu \mathrm{g} / \mathrm{m} \ell$ で明らかな統計学的 有意差を示し，しかも P 群とG 群とは FDP 值 $20 \mu \mathrm{g} / \mathrm{m} \ell$

Table 4 Parenchymal lesions in acute subdural hematoma and their outcome.

\begin{tabular}{cccccc}
\hline CT & $\begin{array}{c}\text { Isodensity } \\
\text { without } \\
\text { mass effect }\end{array}$ & $\begin{array}{c}\text { Isodensity } \\
\text { with } \\
\text { mass effect }\end{array}$ & $\begin{array}{c}\text { High } \\
\text { density }\end{array}$ & $\begin{array}{c}\text { High and } \\
\text { low density } \\
\text { complex }\end{array}$ & $\begin{array}{c}\text { Low } \\
\text { density }\end{array}$ \\
\hline $\begin{array}{c}\text { G } \\
\text { cases })\end{array}$ & 11 & 2 & 2 & 3 & 0 \\
\hline $\begin{array}{c}\text { P } \\
(44 \text { cases })\end{array}$ & 5 & 19 & 6 & 13 & 1 \\
\hline (Mortality) & $(18.8 \%)$ & $(76.2 \%)$ & $(62.5 \%)$ & $(43.8 \%)$ & $(100 \%)$ \\
\hline Total & $\begin{array}{c}16 \\
(25.8 \%)\end{array}$ & $\begin{array}{c}21 \\
(33.9 \%)\end{array}$ & $\begin{array}{c}8 \\
(12.9 \%)\end{array}$ & $\begin{array}{c}16 \\
(25.8 \%)\end{array}$ & $\left(\begin{array}{c}1 \\
1.6 \%\end{array}\right.$ \\
\hline
\end{tabular}

G : good outcome group (good recovery, moderate disability)

P : poor outcome group (severe disability, vegetative state, death) 


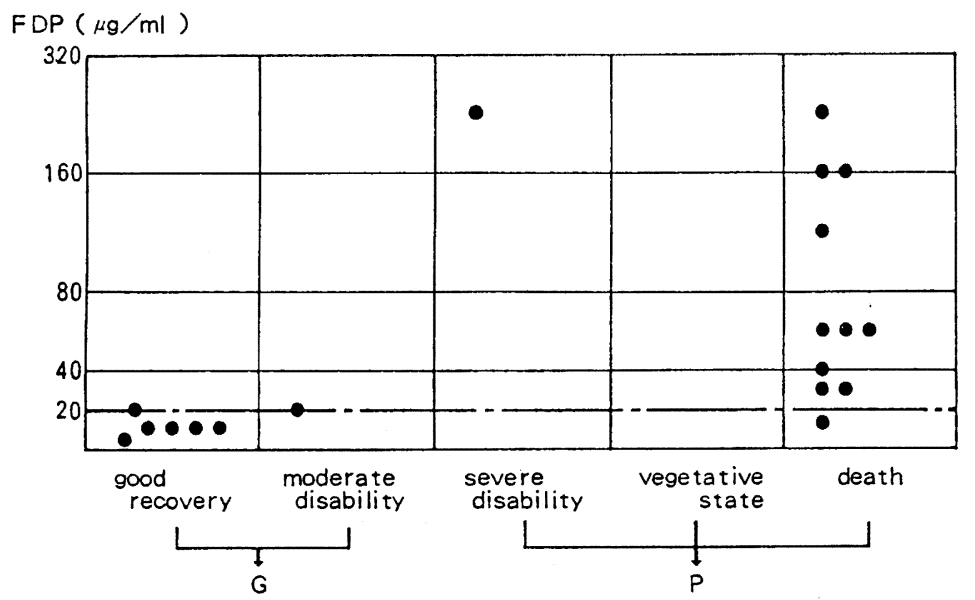

Fig. 3 The figure shows relationship of serum FDP and outcome. Mean value of serum FDP in the poor outcome group $(\mathrm{P})$ is significantly high $(101.3 \mu \mathrm{g} / \mathrm{m} \ell)$, compared with the value 12.9 $\mu \mathrm{g} / m l$ in the good outcome group (G).

Table 5 Serum FDP and parenchymal lesions in acute subdural hematoma.

\begin{tabular}{|c|c|c|c|c|c|}
\hline $\begin{array}{r}\text { CT } \\
\operatorname{FDP}(\mu \mathrm{g} / \mathrm{ml})\end{array}$ & $\begin{array}{l}\text { Isodensity } \\
\text { without } \\
\text { mass effect }\end{array}$ & $\begin{array}{l}\text { Isodensity } \\
\text { with } \\
\text { mass effect }\end{array}$ & $\begin{array}{l}\text { High } \\
\text { density }\end{array}$ & $\begin{array}{l}\text { High and } \\
\text { low density } \\
\text { complex }\end{array}$ & $\begin{array}{c}\text { Low } \\
\text { density }\end{array}$ \\
\hline $\begin{array}{l}\text { Low FDP group } \\
(\leqq 20)\end{array}$ & $(62.5 \%)$ & $(12.5 \%)$ & $\left(25^{2} \%\right)$ & & \\
\hline $\begin{array}{l}\text { High FDP group } \\
(>20)\end{array}$ & & $\begin{array}{c}7 \\
(63.6 \%)\end{array}$ & $(18.2 \%)$ & $(18.2 \%)$ & \\
\hline
\end{tabular}

FDP stands for fibrin and fibrinogen degradation products.

で境されておりこの值を越えたものは 1 例を除き予後不 良であった，すなわち，血中 FDP level は急性硬膜下 血腫の予後に密接な相関を示した. この FDP level が 実際の脸実質損傷の程度とどの様に相関しているかを知 る目的で, Table 5 に示すごとく, low FDP group ( $20 \mu \mathrm{g} / \mathrm{m} \ell)$ と high FDP group $(>20 \mu \mathrm{g} / \mathrm{ml})$ に分け, CT 所見との相関性を分析してみた. low FDP group （8例）ではI（一）を示す例が 5 例 $(62.5 \%)$ と最も多 く, I (+) や H, H \& L の占める割合は少ない. - 方 high FDP group (11例) ではI (十) を示す例が 7 例 $(63.5 \%)$ と最も多く, 次いで $\mathrm{H}(+), \mathrm{H}$ \& L で I （一）は1例も含まれなかった。

\section{IV. 考案}

重症頭部外傷の予後判定に関してはすでに多くの報告
があり, 予後関連因子として意識レベル, 瞳孔反応, 異 常運動反応, oculocephalic, oculovestibular reflex に代 表される脳幹徵候, 誘発電位, CT 所見などが取り上げ られ検討されている2)6) 9) 14)25)26) 27).

著者は急性硬膜下血腫に関して臨床的検討を行った が, severe disability 以上の予後不良 $70 \%$, mortality $51.6 \%$ と不良であり, 臨床的予後不良因子は65歳以上の 高齢, 来院時 GCS score 6 以下, 対光反射消失に代表さ れる脳幹徵候などであり，諸家の報告と一致する2６６７) 10) 26).

急性硬膜下血腫の予後不良の原因として, 脳損傷や脳 腫脹（浮腫）の合併があることは周知のことであるが6) 15) 22), さらに血腫量や血腫形成速度, 二次的脳病変の 有無なども考虑されねばならない时．CT は頭蓋内に発 生した器質的病態, 形態的变化をより明瞭にとらえるこ 
とを可能とした．CT 所見と予後との相関についてはす

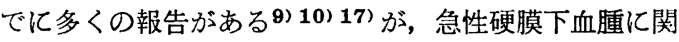
して詳細に検討したものは比較的少ない.今回まず CT 所見より血腫巾と正中偏位の関倸について検討を行っ た。これによると血腫巾すなわち血腫量と正中偏位が高 度なほど予後は不良であることは諸家の報告とも一致す る9) 27)が，血腫巾と正中偏位の比を検討すると急性硬 膜下血腫においては血腫巾, 正中偏位が同程度に大であ るかあるいは血腫巾よりも正中偏位の方が大であるもの の予後が不良で，ことに後者の生命予後が不良であ。 た. このことは血腫量のみならず脳実質損傷の程度や脑 腫脹が急性硬膜下血腫の予後にきわめて重要であること を示唆している. そこでさらに initial CT より脳実質 所見を簡明に評価し得る山浦らの方法27)を用いて急性 硬膜下血腫における脳実質所見を評価した．これによる と, 脳実質損傷の存在が $\mathrm{CT}$ 上明白でないものは62例中 15例 (24\%) であり，その他のむのについては何らかの 脸実質損傷を示す所見が得られた。これらの内最も頻

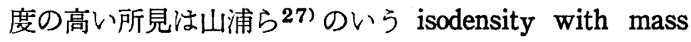
sign であり, 次いで high \& low complex, high density lesionであった．これらを予後との相関でみてみると， 前者すなわち脳実質損傷の明白でないるのは73\%が予後 良好 (good moderate disability) に比し, 脳実質損傷 合併例では 85\%が予後不良 (severe disability〜death) であり, 統計学的有意差を示した. この中でも isodensity with mass sign すなわち血腫量の少ない患側半球 がビマン性に腫脹する病態が最も不良で $90 \%$ poor prognosis であった.

さらに臨床的に GCS score 3,4 点, 対光反射消失, 瞳孔散大など脳幹徴候を伴い，CT 上 isodensity with mass sign, 中脳周囲槽の消失を示するのは術中に angry brain の状熊となり全例死亡しており，手術的治 療の限界であると考元られた. 急性硬膜下血腫の病態に おいてこのような CT 上患側大脳半球の高度な腫脹を示 するのの予後が極めて不良であることはすでに諸家らの 指摘がある7) 8) 10) 27). しかしながら本病態の意味する ところについてはなお議論がある。山浦ら ${ }^{27)}$ は initial $\mathrm{CT}$ 上 detect できない小出血, 浮腫の可能性と脳血管 床拡大の可能性を指摘し, repeated CT にて半数以上に high \& low complex lesion を認めることより前者の可 能性をより強く示唆した. しかしながら本病龑が一時的 な脳血管床の拡大によるものかあるいは多発性脳実質損 傷による浮腫によるものかは治療や予後を考える上で重 要である.

CT導入以来, 頭部外傷に伴って一側をたは両側大脳半
球のビマン性腫脹の発生が知られ, 近年これらはdiffuse brain injury との関係沈いてとらえられている1116). Adams ${ }^{1)}$ は最近の報告で diffuse brain damage は shearing injury 関係し, 基本的には diffuse axonal injury と一側をたは両側の brain swelling, hypoxic brain damage を示し，予後不良と述べている．この中で unilateral brain swelling について acute subdural hematoma を伴 うことが多く, swelling の原因が脳血管床の拡大による 脳血液量の增加によることを指摘した. isodensity with mass sign の本熊が Adams' ${ }^{1}$ のいう diffuse axonal injuryにあると考えれば, 受傷直後より重篤な意識障害を 呈し，極めて予後不良である事実を説明しやすく，また 近年このような指摘も散見される7)。さらに, shearing injury に伴う脳幹の器質的あるいは機能的障害により vasomotor tone が障害され，一側または両側のビマン 性脸腫脹を起すであるうと考えることも可能である11). しかしながら一方, isodensity with mass signを示す ものが repeated CT で高率に挫傷性脳出血を生じてくる ことも知られており 27)，また Zimmerman ら ${ }^{291}$ のいう diffuse shearing injuries of the cerebral white matter のCT 所見を必ずしも伴っていない. 一方 Kobrine ら ${ }^{8)}$ はサルを用いた実験で多発性の脳損傷に伴って fatal な acute brain swelling を発生させることに成功し，これ が組織学的には edema であると報告し, 受傷後 6 時間 以内に発生しうることを示した. 吉野ら ${ }^{28)}$ は急性硬膜 下血腫の dynamic CT の検討より中等度症例では hyperemia が, 重症例では脳自体の広沉な循環障害と brain edema が存在することを指摘している．伊藤ら4) も脳血 管床の拡大の可能性の他に二次的に加わる虚血あるいは hypoxia による広汎な脳損傷の結果として edema を生 じる可能性を指摘している.

一方予後の観点から見ると, 急性硬膜下血腫 I $(+)$ の病態は大部分予後不良ではあるが，少数ながら予後が 比較的良いむのも経験される. これは CT 上 diffuse brain swelling を示するのの中に予後良好例と不良例が 存在すること 3) 8) 29) と同様の 理 由によることが考えら れる.

これらの事実は I (+) を示す病態の中に脳幹の mild axonal injury に伴って一時的に脳血管床が拡大寸 るものと severe diffuse axonal injuryを伴うもの (diffuse brain damage), さらに shearing injury による多 発性脳損傷と脳浮腫を伴う場合の基本的には 3 つの病 態が関係する可能性が考えられる.ささらに血腫や浮腫, 腫脹に伴って発生する二次的脳損傷 (hypoxia, ischemia) が加わり，その病態をより複雑なるのとし，予後と密接 
Pathophysiological Mechanism in Acute Sudural Hematoma

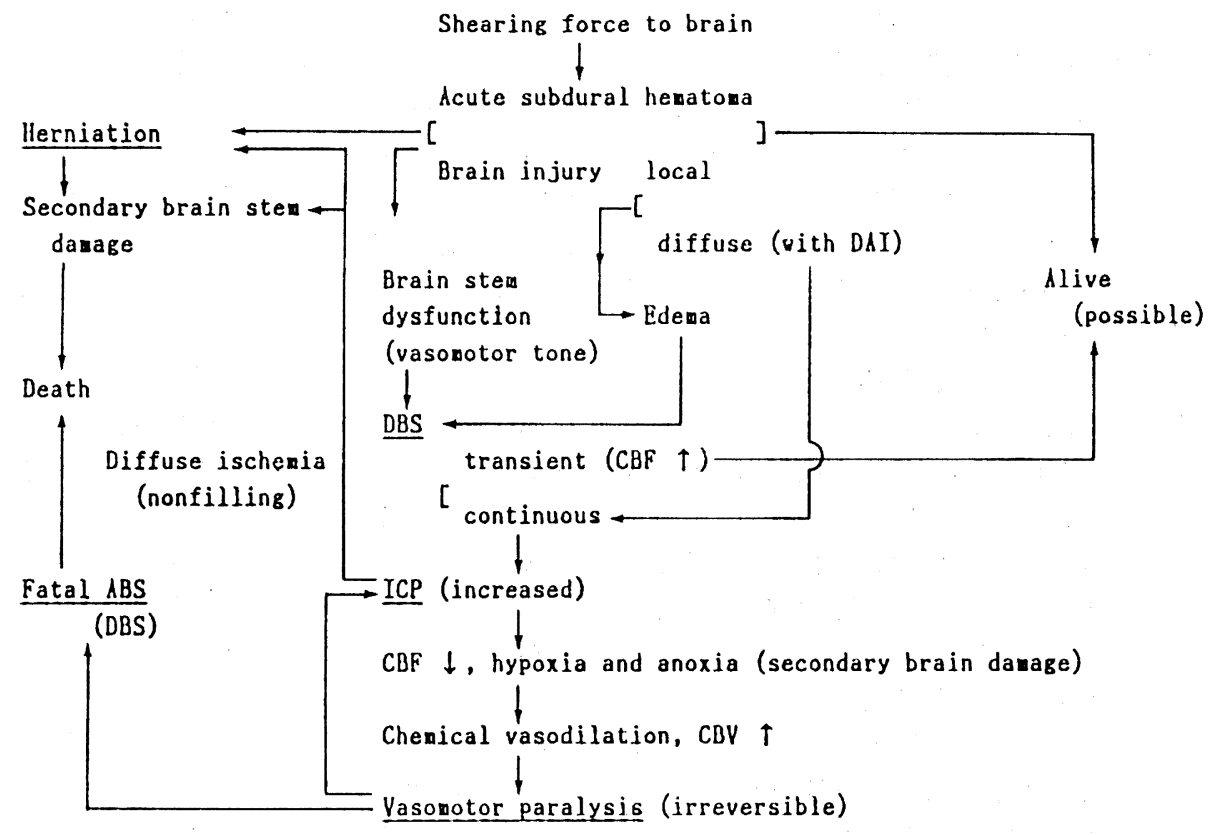

Fig. 4 Pathophysiology in acute subdural hematoma.

DAI : diffuse axonal injury

$\mathrm{CBV}$ : cerebral blood volume

ABS : acute brain swelling
DBS : diffuse brain swelling

ICP : intracranial pressure

$\mathrm{CBF}$ : cerebral blood flow
に関係する可能性が推測される. initial CT では空間分 解能や partial volume effect 等によりこれらを有勃に 鑑別し得ないのであろう．急性硬膜下血腫におけるこれ らの関係を病態生理に基ゔいて Fig. 4 亿図示した.

さて, 今回検討した FDP 測定の頭部外傷における意 義についてはすでに Sandeら 24) 25)，Minerら 12)，杉浦 ら ${ }^{19)}$ の報告がある. FDP の増加は線溶現象の六進を意 味するが，頭部外傷においては脳実質に大量に含まれる 組織 thromboplastin が外傷による組織破壊に伴って血中 に流入し，凝固系が充進し， fibrin， fibrinogen が増加 し，これに伴う線溶六進の結果 FDP の増加が見られる と解釈されている19)。すなわち頭部外傷に扔ける FDP の上昇は脳組織破壊の程度を敏感に反映することが示唆 されている12) 19２4２5)．著者むかつて頭部外傷につい て凝固線溶系の变化を検討 (FDP, fibrinogen, 血小板, PT, APTT) し，FDP が最も sensitive に脳実質損傷と 相関することを知った ${ }^{13)}$ ．今回 急性硬膜下血腫19例に おいて受傷早期に FDP の測定を行いその意義を検討し た. 予後との相関性については G 群の平均値 $12.9 \mu \mathrm{g} / \mathrm{ml}$ に比し, P群 $101.3 \mu \mathrm{g} / \mathrm{ml}$ と統計学的に有意差を示し, prognostic な価值があると考元られた。 また，脳実質， 所見との対比検討の結果 low FDP $(\leqq 20 \mu \mathrm{g} / m l)$ ) 8 例 中 5 例 $(62.5 \%)$ が isodensity without mass sign で予 後良好であるのに比し， high FDP ( $\geqq 20 \mu \mathrm{g} / m \ell)$ 11例 すべてが isodensity with mass effect, high density, high \& low density で予後は不良であった. このこと は FDP の上昇が脳実質損傷を密接に反映している可能 性を示唆している. ことに isodensity with mass effect を示すむのの 8 例中 7 例が FDP 高值を示したことは興 味深い。しかしながら頭部外傷における凝固線溶系の变 化に関しては他臟器損傷や骨折の有無, さらに外傷に伴 うショック状態や asphyxia, 脱水なぞ 全身的要因の関 与も考虑されなくてはならない18)，今回の検討からは 他蔵器損傷合併例は省いてあり，また頭蓋骨折について はそれほどの影響はもたらさないとの報告もある12) 24) 25)ため，これらは無視し得ても，受傷後に生じた一過 性のショック状態や asphyxia の関与の可能性は免れが たい.ことに high FDP を示した群は重篤な臨床徴候 と予後を持ったものであることを考えると high FDP は 脳組織損傷の程度をある程度反映する一方, これらの全 
身状態の影響を受けた可能性も考虑されねばならない。 これらに関する今回の著者の検討はなお十分ではないが このような異常が一過性か持続性であるかも予後との相 関を論じる上で重要であり，今後さらに検討したい。し かしながら少なくとも生命予後の面では prognostic 価 值があると考えられた．一方，FDP 高值が前述したI （+）の病態で 高率に認められ，予後不良であったこと は興味深い. I (+) の病態注いて initial CT 上, 明 らかにし得ない多発性脳損傷の存在や二次的な脳虚血, hypoxic damage による広沉な脳損傷を間接的に反映し ている可能性も示唆される.

一方, 急性硬膜下血腫を第 1 篇において検討した力学 的観点より考えると，今回対象とした急性硬膜下血腫62 例中受傷機転を明白に知り得たのは 29例（交通事故 19 例, 転落事故10例) であるが, 力学的諸因子中頭部打撲 部位は交通事故では後頭部12例, 前頭部 3 例, 側頭, 頭 頂部各 2 例, 転倒事故では後頭部 6 例, 側頭, 頭頂部各 2 例で，いずれにおいても後頭部打撲の占める割合が圧 倒的に高かった．急性硬膜下血腫の本態はその多くを同 時に合併する脳損傷に負うところが大であり，その部位 や種類が予後を規定する重要な因子であることをすでに 述べたが, 今回の力学的検討の結果は後頭部打撲と矢状 方向の外力が bridging vein の破綻や重篤な脳損傷を発 生しがちであることを示唆している.

このことは矢状方向の外力, 回転加速度衝撃が shearing force を発生し, 脳損傷を生じるという Holbourn （第1 篇文献22）の実験仮説を支持しているのかもしれ ない.しかしながら第 1 篇で述べたごとく，打撲部位を もって外力の方向, 性状を正確に推定することは困難で あることもまた留意されねばならない。さらに予後不良 例, すなわち重篤な脳損傷合併例は交通事故では衝突速 度は予後不良例で平均 $48.1 \mathrm{~km} / \mathrm{h}$ と高速度で発生してお り, 転落事故でも予後は落下距離と比例する傾向があっ た.このことは重篤な脳損傷の発生には頭部に一定以上 の外力が加わる必要があるという第 1 篇の結果を急性硬 膜下血腫に㧊いても同様に示唆している.

これらの事実は事故発生時の外力の評価，すなわち速

文献

1) Adams, J.H. : Diffuse brain damage in human and experimental head injury. Neurosurgeons, 6, 46 53, 1987.

2) Becker, D. P., Miller, J. D., Ward, J.D., Greenberg, R. P., Young, H. F. and Sakalas,
度, 落下距離, 頭部打撲部位, 外力の方向などを知るこ そができれば急性硬膜下血腫の発生や合併脳損傷の程度 をある程度予知し予後予測が可能であることを示してい る.また，簡便な脳損傷の定性定量的評価の一手段とし て今回著者の検討した FDP の測定を加未すれば，初回 CT 上必ずしも明らかにし得ない脳損傷の存在（一次 的, 二次的脳損傷）の推定や，より正確な予後予測が臨 床的に可能であることを示唆するものである.

\section{V. まとめ}

急性硬膜下血腫62例の予後関連因子，CT における脸 実質所見について検討を加えると共に，19例において血 中 FDP の測定を行いその意義を検討した.

1) 予後不良 (SD, VS, D) $70.9 \%$, mortality $51 \%$ であり, 臨床的予後不良因子は 65 歳以上の高齢, GCS score 6 以下, 対光反射消失, 除脳硬直であった.

2) initial CT 上脳損傷の所見は70\%にみられ（I $(+), H \& L, L)$, これらの予後は著しく不良であっ た (mortality $70.6 \%$ ).

3 ）血中 FDP は $20 \mu \mathrm{g} / \mathrm{ml}$ を越えるものの生命機能予 後が極めて不良（mortality 約 $91 \%$ ）であり，全例 initial CT 上脳実質損傷所見を伴い, 脳損傷 (一次性, 二 次性）の程度や予後と密接に相関することが示唆され， 急性硬膜下血腫の予後判定, 脳損傷の定量的評価の一助 として有用であると考えられた。

4 ）急性硬膜下血腫の病態生理について考察した.

本論文の要旨は第43回日本脳神経外科学会総会（昭和 59年10月，千葉），第12回 日本救急医学会総会（昭和59 年11月，広島）において発表した.

稿を終えるに臨み，御懇篤なる御指導を賜りました恩 師松村 浩教授に深甚の謝意を捧げますと共に, 終始御 指導, 御校閲を賜りました栗本匡久講師に心より深謝の 意を表します。また，重要な資料を提供して頂いた各部 署の警察官各位, 種々の御協力を頂いた教室員各位, な らびに秘書の粟田泰子殿に御礼申し上げます。

R. : The outcome from severe head injury with early diagnosis and intensive management. J. Neurosurg. , 47, 491 502, 1977.

3）原岡 稜, 古場群已, 伊藤良則, 三輸哲郎, 斎藤 守男, 和岡勇男 : 頭部外傷急性期におけるdiffuse 
or generalized brain swelling の検討. 一 CT scan による経時的観察より一，神経外傷，3，45〜 52, 1980.

4）伊藤梅男, 鬼頭溥裕, 岡田洽大, 田田博樹, 稻葉 頭部外傷急性期における兴腫脹，ならびに挫 傷性脳浮腫の経時的変化. 神経外傷, 6, 39〜 48, 1983.

5) Jennett, B. and Bond, M. : Assessment of outcome after severe brain damage. A practical scale. Lancet, 1, 480 484, 1975.

6) Jennett, B., Teasdale, G., Braakman, R., Minderhoud, J., Heiden, J. and Kurze, T. : Prognosis of patients with severe head injury. Neurosurgery, 4, 283 289, 1979.

7) 北村純司, 志熊道夫, 大村武久, 岩田 隆, 太田 富雄：急性期頭部外傷の予後不良因子. 神経外 傷，5，115～121， 1982.

8 ) Kobrine, A. I. and Kempe, L.G. : Studies in head injury. - Part I : An experimental model of closed head injury. Surg. Neurol., 1, 34 37, 1973.

9）栗本匡久, 山内康雄, 久保田千晴, 河村悌夫, 松 本明宏, 野川徳二：急性硬膜下血腫の病態ならび に CT 像汇関する一考察. 神経外鹪，3，58～59, 1980.

10）楠元和博, 西沢輝彦, 門田紘輝, 朝倉哲彦, 小林 栄喜, 三原忠紘：CT 所見を中心とした重症頭部 外傷患者の予後判定について。神経外傷， $\mathbf{5}, 39$ 〜8, 1982.

11) Langfitt, T. W., Weinstein, J.D. and Kassell, N.F. : Cerebral vasomotor paralysis produced by intracranial hypertension. Neurology, 15, 622 641, 1965.

12) Miner, M.E., Kaufman, H. H., Graham, S. H., Harr, F. H. and Gildenberg, P. L. : Disseminated intravascular coagulation fibrinolytic syndrome following head injury in children. Frequency and prognostic implication. J. Pediat., 100, 687 691, 1982.

13）水野 誠，栗本匡久，河村悌夫，松村 浩：頭部 外傷急性期における凝固線溶能の検討一特に脳損 傷の程度, 予後との関連性について. 救急医学, 臨時増刊号 (3 月), 319～320, 1985.

14）水野 誠，栗本匡久，山内康雄，染田邦幸，松村 浩：外傷性脳室内出血一22症例の臨床的検討一.
Neurol. Med. Chir. (Tokyo), 28, 380 386, 1988.

15）中村紀夫：頭部外傷急性期に行われる 减圧開頭 術. 災害医学, 16, 643〜647, 1973.

16）中村紀夫：ビ慢性脳損傷の史的展望と発生機序. Neurosurgeons, 6, 3〜10, 1987.

17）小野純一, 山浦 晶, 砬部勝見, 小滰 勝, 渡辺 䅈郎, 佐伯直勝, 中村孝雄, 牧野博安: 重症頭部 外傷の CT 所見の分析一脳梁, 基底核, 脳幹部の hemorrhagic lesions を有する症例の検討一. 神経 外傷, 6, 221 226, 1983.

18）澤田裕介, 坂本敏久, 西出和幸, 定光大海, 吉岡 敏治, 杉本 㑆, 越野兼太郎 : 遅発性脳内血腫の 発現機序. 神経外傷，6，69～76, 1983.

19）杉浦 誠，森，伸彦，今永浩寿，神保 実，喜多 村孝一, 河野 宏：急性頭部外傷における FDP の変動. 救急医学, 7, 807 813, 1979.

20) Teasdale, G. and Jennett, B. : Assessment of coma and impaired consciousness. Lancet, 2, 81 84, 1974 .

21）坪川孝志：ビ慢性脳損傷一その疾患概念と診断に ついて. Neurosurgeons, 6, 11 20, 1987.

22）堤 晴彦, 淵之上徳郎，有賀 徹，三井香児，間 中信也：成人急性硬膜下血腫一脳挫傷併存の有無 による症状並びに予後の差異について. 神経外 傷, 5, 235〜242， 1982.

23）堤 晴彦，川原信隆，小野一之，高橋久人，福家 伸夫，有賀 徹，豊岡秀訓，三井香児，都築政 和, 高倉公朋 : 脳挫傷の定量法一原理と方法およ び臨床的検討一. 神経外傷, 6, 263〜265, 1983.

24） van der Sande, J. J., Veltkamp, J. J. , Boekhout-Mussert, R. J. and Bouwhuis-

Hoogerwerf, M. L. : Head injury and coagulation disorders. J. Neurosurg., 49, 357 365, 1978.

25) van der Sande, J. J. , Veltkamp, J. J. , Boekhout-Mussert, R. J. and Vielvoye, G. J. : Hemostasis and computerized tomography in head injury. Their relationship to clinical features. J. Neurosurg., 55, 718 724, 1981.

26) Weir, B. and Miller, J. : Early identification of brain injury. Neurosurgeons, 6, 21 26, 1987.

27）山浦 晶，小野純一，中村孝雄，有賀直文，堀江 武, 篠原義蜸, 礒部勝見, 国保能彦, 牧野博安: 
頭部外傷における CT 所見の分析. 脳神経外科, 8, 789 802, 1980.

28）吉野英二, 山木垂水, 榎口敏宏, 堀川義治, 平川 公裁：急性硬膜下血腫における dynamic CT の 検討. 一diffuse cerebral swelling の病態につい
て一. CT 研究, 5, 53〜64, 1983.

29) Zimmerman, R.A., Bilaniuk, L.T. and Gennarelli, T. A. : Computed tomography of shearing injuries of the cerebral white matter. Radiology, 127, 393 396, 1978. 


\title{
（欧 文 抄 録）
}

\section{Dynamic Assessment and Quantitative Analysis of Acute}

\section{Head Injury}

\author{
Part 2 A Quantitative Evaluation of Brain Damage \\ with Acute Subdural Hematoma \\ -With special reference to the significance of serum \\ FDP measurement and the prognosis-
}

\author{
Makoto Mizuno \\ Department of Neurosurgery, Kansai Medical University, \\ Moriguchi, Osaka 570, Japan \\ (Director : Professor Hiroshi Matsumura, M. D., Department \\ of Neurosurgery, Kansai Medical University)
}

Acute subdural hematoma was studied clinically in 62 cases, with special reference to the prognostic factor and the complicated brain injuries seen on the initial CT.

Furthermore, serum fibrin and fibrinogen degradation products (FDP) in acute stage were measured in 19 cases and their significance was discussed.

Though the prognosis proved to correlate with the complicated brain injuries and to be very poor, it was suspected that it varied according to some basic pathophysiology in acute subdural hematoma, that is, the location and the degree of brain tissue injuries and associated edema or brain swelling.

Since the initial CT does not necessarily mirror the whole brain tissue damages or their pathophysiology in acute subdural hematoma, a quantitative study of the brain injuries becomes more significant.

The measurement of serum FDP in the present series showed a good correlation with the prognosis and, also, it was suggested that serum FDP would possibly reflect the degree of the brain tissue injuries (both of primary and secondary injuries). Thus, measurement of serum FDP may be of much value as an aid for analytical study of the clinical state and the quantitative evaluation of brain tissue injuries in acute subdural hematoma. 